\title{
Bahasa dan Pembentukan Cittra dalam Komunikasi Periklanan di Televisi
}

\begin{abstract}
Anwar Efendi"
*) Penulis adalah dosen tetap di Fakultas Bahasa dan Seni Universitas Negeri Yogyakarta (UNY).

Abstract: Language in an advertisement has two functions. The first is language as a means of communication and the second is language as a means of forming social reality. The first function deals with its use as a source of information, while the second deals with its use as a creative art in engineering expected world or condition. As a source of information, the language becomes a means of delivering thue information about a certain product being advertised to people. It describes all the details of the product, such as the use, advantages, and ease. This is intended to make consumers know well about the product and decide t buy it. As a means of forming social reality, the language in advertisement is used to create an image about the product for the consumers. This process of building image represents in making association between the product and life style, social class, and symbols of modemily, Keywords: advertisement, image, and communication.
\end{abstract}

\section{PENGANTAR}

Kata iklan (advertising) berasal dari bahasa Yunani, yang artinya kurang lebih adalah 'menggiring orang pada gagasan'. Adapun pengertian iklan secara komprehensif adalah "semua bentuk aktivitas untuk menghadirkan dan mempromosikan ide, barang, atau jasa secara nonpersonal yang dibayar oleh sponsor tertentu”. Secara umum, iklan berwujud penyajian informasi nonpersonal tentang suatu produk, perusahaan, atau toko yang dijalankan dengan kompensasi biaya tertentu. Dengan demikian, iklan merupakan suatu proses komunikasi yang bertujuan untuk membujuk atau menggiring orang untuk mengambil tindakan yang menguntungkan bagi pihak pembuat iklan. ${ }^{1}$

Pada awal pemunculannya, iklan di Indonesia lebih berupa iklan-iklan pribadi daripada iklan perusahaan atau institusi. Oleh karena perkembangan teknologi cetak yang masih tradisional, iklan-iklan tersebut lebih menyerupai iklan baris seperti yang ada di surat kabar sekarang ini.

Selanjutnya, perkembangan iklan di Indonesia mengikuti model sejarah perkembangan media pada umumnya. Pada awalnya, masyarakat Indonesia mengenal iklan modern melalui surat kabar, karena pada saat itu masyarakat baru mengenal surat kabar. Kemudian, ketika masyarakat Indonesia mengenal media radio, maka lahirlah iklan radio. Terakhir, pada saat teknologi televisi sudah berkembang, maka lahirlah iklan televisi dan yang lebih modern lagi adalah iklan lewat dunia maya (internet) yang jangkauannyalebih luas.

Dalam kehidupan masyarakat dewasa ini, televisi telah menjadi media komunikasi terpopular dan digemari seluruh lapisan masyarakat. Televisi adalah benda mati yang mampu "berinteraksi" dengan manusia, tidak sekadar melalui kognisi, namun juga secara fisik, melalui penggabungann teknologi televisi, telepon, dan internet. Televisi adalah media audio-visual yang murah dan dimiliki secara umum dan mudah dijangkau oleh mayoritas masyarakat dari berbagai golongan. Dengan kata lain, televisi adalah media massa yang merakyat dengan kemampuan publikasi yang maksimal sehingga televisi disebut juga sebagai saluran budaya massal.

Dengan pertimbangan kekuatan dan keunggulan yang dimiliki televisi itulah para produsen memilih televisi sebagai media untuk mengenal produk-produk yang dihasilkan. Pengenalan produk tersebut dikemas dalam iklan yang nantinya disiarkan atau ditayangkan di televisi. Para produsen menganggap bahwa televisi merupakan media yang paling efektif untuk 


\section{JURNAL DAKWAH DAN KOMUNIKASI}

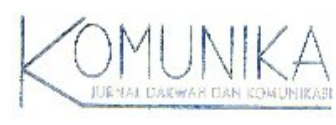

mengenal produk kepada masyarakat luas. Dunia periklanan lewat televisi merupakan media paling ideal untuk penyampaian ide-ide iklan karena televisi adalah media yang memiliki kemampuan maksimal.

\section{PRINSIP KOMUNIKASI DALAM IKLAN}

Sebagai bagian dari dunia komunikasi, iklan menggunakan bahasa sebagai alat utama untuk pengambaran sebuah realitas. Dalam iklan, bahasa digunakan untuk semua kepentingan, termasuk dalam rangka melakukan persuasi. Dalam perspektif semiotika, persuasi salah satunya dapat dilakukan dengan logika "kebohongan" atau "teori dusta".

Teori dusta yang dikemukakan oleh Umberto Eco dikembangkan berdasarkan konsep dalam semiotika. Pada dasarnya semiotika berhubungan dengan segala sesuatu yang dapat dianggap sebagai tanda. Tanda adalah segala sesuatu yang dapat dianggap sebagai pengganti sesuatu yang lain secara signifikan. Sesuatu yang lain itu tidak harus ada atau benar-benar ada di suatu tempat pada saat tanda menggantikannya. Semiotika mengkaji segala sesuatu yang dapat digunakan untuk mengelabui atau mengecoh. Jika tidak dapat digunakan untuk mengecoh, berarti ia tidak dapat digunakan untuk "mengatakan" suatu hal.

Pada umumnya, iklan sebagai suatu bentuk komunikasi memiliki sifat dan kecenderungan yang mendekati logika pembohong. Akan tetapi, kebohongan tersebut sering masuk akal sehingga sulit untuk dibantah. Berbohong, mendustai, dan mengecoh dalam dunia iklan tidak semata-mata berhubungan dengan maksud merugikan atau menipu khalayak. Semua tindakan tersebut lebih diarahkan pada upaya membujuk masyarakat atau konsumen. ${ }^{3}$

Dalam iklan, penggunaan bahasa berkaitan dengan dua hal, yaitu (1) bahasa sebagai media komunikasi, dan (2) bahasa sebagai media penciptaan realitas sosial. Bahasa sebagai media komunikasi, yakni penggunaan bahasa iklan dilihat sebagai bentuk informasi. Sementara itu, bahasa sebagai media penciptaan realitas sosial, penggunaan bahasa sebagai bagian dari seni kreatif dalam rangka merekayasa duniayang diinginkan.

Sebagai pemberi informasi, bahasa dalam iklan merupakan sarana untuk menyampaikan informasi yang sebenarnya kepada masyarakat tentang produk yang akan ditawarkan. Bahasa digunakan untuk mendeskripsikan dan menggambarkan seluruh kenyataan secara terperinci tentang suatu produk. Sasaran utama yang ingin dicapai adalah agar konsumen dapat mengetahui dengan baik produk itu sehingga memutuskan untuk membeli. Yang ditekankan di sini adalah agar konsumen tahu tentang produk tersebut, seperti kegunaannya, kelebihannya, dan kemudahan-kemudahan yang diperoleh jika menggunakan produkitu.

Selanjutnya, sebagai media penciptaan realitas sosial, bahasa dalam iklan digunakan untuk membentuk citra pada suatu produk. Pencipataan realitas sosial tersebut berhubungan dengan upaya membangun citra (image) bagi konsumen. Proses pencitraan tersebut berupa penciptaan asosiasi antara produk dengan gaya hidup, stratifikasi sosial, dan simbol-simbol modernisme.

Iklan adalah bagian penting dari serangkaian kegiatan mempromosikan produk yang menekankan unsur citra. Dengan demikian, objek iklan tidak sekadar tampil dalam wajah yang utuh, tetapi melalui proses pencitraan. Citra dari sebuah produk lebih mendominasi daripada produk itu sendiri.

Para pembuat iklan memiliki keyakinan bahwa iklan yang ditampilkan dengan pencitraan yang kuat akan lebih besar kekuatannya dalam mempengaruhi pemirsa. Proses pencitraan lebih menekankan pada upaya membangun realitas sosial "baru" pada diri pemirsa melalui iklan yang ditawarkan. Realitas "baru" yang diciptakan tersebut sebenarnya merupakan realitas semu. Artinya, realitas yang ditampilkan melalui pencitraan tersebut sebenarnya sulit terjadi dalam kehidupan nyata di masyarakat. Akan tetapi, karena kuatnya penetrasi pencitraan melalui iklan di televisi, masyarakat seringkali menganggap bahwa realitas sosial yang diciptakan melalui iklan itu dapat terjadi dalam kehidupan sehari-hari.

Citraan (image), yakni isi pesan yang mencoba menampilkan asosiasi antara produk dan gaya hidup, masyarakat kelas atas (glamorous people), dan simbol-simbol modernisasi. Citra itu sendiri sebagai suatu konsep mengandung pengertian keseluruhan informasi tentang dunia ini yang telah diolah, diorganisasikan, disimpan individu. ${ }^{4}$ Citra juga diartikan sebagai suatu dunia menurut persepsi kita karena ia adalah gambaran tentang realitas dan tidak harus sesuai dengan realitas. 


\section{JURNAL DAKWAH DAN KOMUNIKASI}

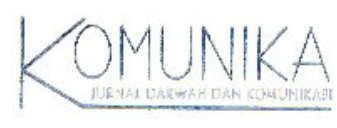

Dalam kaitannya dengan dunia periklanan, pembuat iklan (produser) berusaha melakukan pembentukan dan pengubahan citra tertentu sesuai dengan produk yang ditawarkan. Seperti yang dikatakan Robert, komunikasi, termasuk komunikasi periklanan, tidak secara langsung menimbulkan perilaku tertentu, tetapi cenderung mempengaruhi cara kita mengorganisasikan citra kita tentang lingkungan. Pada akhirnya citra itulah yang mempengaruhi cara kita berperilaku. ${ }^{5}$

Proses pembentukan pencitraan dalam iklan tersebut salah satunya melalui pemanfaatan kekuatan bahasa. Bahasa sebagai suatu sistem tanda digunakan secara maksimal dalam iklan televisi. Dalam hal ini, sistem tanda dalam bahasa digunakan untuk memperjelas citra yang dikonstruksikan. Dengan demikian, apa yang ada dalam berbagai makna iklan di televisi sesungguhnya adalah realitas bahasa itu sendiri. ${ }^{6}$

Pada umumnya pencitraan dalam iklan televisi disesuaikan dengan khalayak yang menjadi sasaran iklan tersebut. Siapa yang menjadi tujuan utama dari produk yang diiklankan itulah yang dijadikan pertimbangan dalam membentuk pencitraan. Tamagola 7 mengemukakan beberapa kategori pencitraan iklan di televisi, yaitu (1) citra feminisme, (2) citra maskulin, (3) citra eksklusif(kemewahan), (4) citra kelas sosial, dan (5) citra kenikmatan.

Proses pembentukan pencitraan dalam iklan tersebut salah satunya melalui pemanfaatan kekuatan bahasa. Bahasa sebagai suatu sistem tanda digunakan secara maksimal dalam iklan televisi. Dalam hal ini, sistem tanda dalam bahasa digunakan untuk memperjelas citra yang dikonstruksikan. Dengan demikian, apa yang ada dalam berbagai makna iklan di televisi sesungguhnya adalah realitas bahasa itu sendiri. ${ }^{8}$

Sebagai bagian dari dunia komunikasi, iklan menggunakan bahasa sebagai alat utama untuk melakukan penggambaran tentang sebuah realitas. Dalam hal ini, bahasa digunakan untuk dua kepentingan sekaligus. Pertama, bahasa digunakan sebagai salah satu sarana untuk mendeskripsikan realitas barang (produk) yang akan ditawarkan/diiklankan. Kedua, setelah deskripsi barang ditampilkan, bahasa juga digunakan untuk membentuk citra pada barang tersebut. Kutipan iklan di bawah ini menegaskan uraian tersebut.

"Nach itulah bedanya, hemaviton energy drink, pelepas dahaga, penambah tenaga, hemaviton sisi cerah kehidupan".

"Penampilan rambut bisa menipu, saat menyentuh baru percaya. Shampo Pantene, kuyakin saat kusentuh, begitu sempurna, terasa sehatnya, itulah pantene”.

“Keceriaan bayi adalah kebahagiaan ibu.Zwitsal dengan avobiotonic, begitu lembut dan aman merawat kulit”.

“Ciptadent dengan calcium, hyge-life, menjadikan gigi putih bersih, ekstrakuat, gusi ekstra sehat, ekstra segar, dan gigicemerlang”.

Penggunaan kata-kata seperti hemaviton energy drink, Zwitsal dengan avobiotonic, dan Ciptadent dengan calcium, hyge-life adalah cara untuk mendeskripsikan realitas barang (produk) yang akan ditawarkan/diiklankan. Selanjutnya, penggunaan kata-kata seperti hemaviton sisi cerah kehidupan, begitu sempurna, kebahagiaan ibu, dan, ekstra kuat, gusi ekstra sehat, ekstra segar, dan gigicemerlang adalah sarana untuk membentuk citra pada barang tersebut.

Berdasarkan uraian di atas, dapat disimpulkan bahwa penggunaan bahasa dalam iklan memiliki dua tujuan. Pertama, bahasa digunakan sebagai media komunikasi, dan kedua bahasa digunakan sebagai sarana menciptakan sebuah realitas (untuk membentuk citra). Sebagai media komunikasi, penggunaan bahasa dalam iklan untuk kepentingan yang bersifat informatif. Bahasa digunakan untuk menginformasikan dan mendeskripsikan produk atau barang yang diiklankan. Sementara itu, sebagai media penciptaan realitas, bahasa iklan lebih bermakna seni, yakni bahasa digunakan untuk menciptakan dunia yang diinginkan. Bahasa digunakan untuk menghadirkan citra (image) dalam diri khalayak yang menjadi sasaran iklan. Bentuk pencitraan tersebut berkaitan dengan perilaku dan gaya hidup masyarakat.

\section{ASPEK RETORIK DALAM IKLAN}




\section{JURNAL DAKWAH DAN KOMUNIKASI}

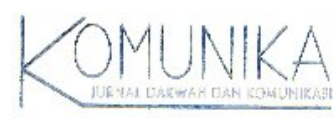

Dalam dimensi teks yang diteliti adalah struktur teks. pemilihan dan penyusunan kata, kalimat, proposisi, retorika dalam wacana merupakan bagian dari strategi dari pihak pembuat teks (penulis atau pembicara). Pemakaian kata tertentu, kalimat tertentu, dan gaya bahasa tertentu bukan semata-mata dipancang sebagai cara berkomunikasi, tetapi dipandang sebagai strategi berkomunikasi.

Dalam dunia periklanan, strategi berkomunikasi sebagai bagian dari upaya mempengaruhi pendapat umum, menciptakan dukungan, memperkuat legitimasi, dan mengeliminasi lawan. Struktur wacana adalah cara yang efektif untuk melihat proses retorika dan persuasi yang dijalankan ketika seseorang menyampaikan pesan. Kata-kata tertentu dipilih untuk mempertegas sikap, membentuk kesadaran kolektif, dan sebagai sarana persuasi.

Sebagai salah satu bentuk komunikasi, iklan menggunakan bahasa sebagai salah satu media penyampaian pesan. Dengan kata lain, bahasa merupakan bagian penting dari komunikasi, termasuk komunikasi periklanan. Komunikasi dalam iklan pada dasarnya juga sebagai salah satu upaya menyampaikan ide, emosi, dan keinginan dengan format dan variasi tertentu. Oleh karena itu, pemanfaatan bahasa dalam iklan juga berkaitan dengan fungsi hakiki bahasa itu sendiri.

Aspek verbal merupakan kondisi penting dalam suatu program periklanan. Kenyataannya untuk beberapa produk, ketiadaan komunikasi lisan atau kata-kata sebagai perwujudan aspek verbal dapat berakibat fatal karena komunikasi lisan atau kata-kata mempunyai kredibilitas, komprehensif, dan berpengaruh kepada khalayak. Hal itu diperkuat dengan kenyataan bahwa bahasa (verbal) dapat digunakan sebagai alat bantu memori. Bahasa verbal membuat memori lebih efisien bila kita akan menyandi suatu pesan. Para peneliti menunjukan bahwa ternyata kita lebih mudah mengenali kembali warna, isyarat, suara yang mungkin sulit disifatkan, bila sudah dinamai dengan menggunakan bahasa verbal. Bahkan dapat dikemukakan bahwa memori manusia pada pokoknya berbentuk verbal. ${ }^{9}$

Dalam hubungannya dengan dunia periklanan, pemanfaatan kekuatan bahasa tampak melalui bentuk-bentuk retorik pada penataan dan pengolahan pesan verbal yang disampaikan. Aspek-aspek yang berkenaan dengan retorik selanjutnya diuraikan sebagai berikut.

\section{Hiperbola}

Hiperbola adalah salah satu gaya bahasa yang mementingkan penampilan gagasan yang berlebihan. Gaya bahasa hiperbola menggunakan pernyataan dengan membesar-besarkan atau melebih-lebihkan produk yang ditawarkan. Melalui klaim atau pernyataan yang berlebihan dan bahkan seringkali tidak sesuai dengan kenyataan, produsen ingin membentuk kesan mendalam tentang produkyang ditawarkan. Pernyataan yang berlebihan itu biasanya dihubungkan dengan kandungan bahan baku barang, fungsi barang, kemampuan atau keandalan, dan sebagainya.

Sebagai suatu isi pesan yang menekankan aspek emosional, apakah klaim atau pernyataan tersebut dapat diterima logika, tidak menjadi hal yang penting. Yang terpenting adalah penanaman kesan yang kuat pada diri konsumen menyangkut semua hal yang ada pada barang. Prinsip hiperbola, sebagaimana prinsip iklan pada umumnya, yang terpenting adalah konsumen mengenal dan mempunyai kesan terhadap produk yang ditawarkan. Berkaitan dengan keputusan apakah mereka akan membeli atau tidak membeli merupakan soal lain lagi.

Contoh iklan:

"Rinso cair, deterjen modern dalam bentuk cair. Padahal sempurna keampuhan daya bersih bubuk deterjen dengan kelembutan bahan cuci cair.Ampuhmengatasikotor dannoda, namum lembutuntuktangan danpakaian. Rinsomembersihkanpaling bersih."

"Deterjenku, cucian segunung, noda sekotor apapun, bereeess. Deterjenku, yang lain putuuss! Jelas DAIA, busa melimpah, super bersih, super harum. Pakai DAIA, lupakanyanglain."

"Sejakawal, filma begitujermih begitu sehat. Cintajermihmya,jernih cintamya."

"Kecap $\mathrm{ABC}$ pemuh selera dalam kebersamaan, pemuh kemesraaan dalam kehangatan keluarga.... Kecap ABC, untuk semua hidangan dalam segala kebersamaan. KecapABC bagian dari keluarga Anda." 


\section{JURNAL DAKWAH DAN KOMUNIKASI}

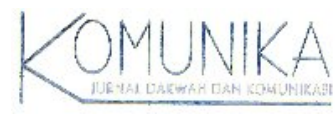

\section{Kata Aksi}

Kata aksi adalah pemanfaatan kata kerja dalam penyampaian pesan verbal. Kata aksi yang berupa kata kerja digunakan untuk memberikan suatu derajat keurgensian pada pesan iklan. Menurut Jefkins ${ }^{10}$ kata aksi atau kata kerja digunakan agar pesan verbal dalam iklan dapat lebih bersifat cair/mengalir dan tidak kaku. Hal itu dengan pertimbangan pada intinya periklanan juga suatu bentuk komunikasi.

Melalui pemanfaatan kata aksi atau kata kerja akan terbentuk jalinan relasional antara produsen sebagai penyampai pesan (komumikator) dengan konsumen sebagai penerima pesan (komumikate). Kata aksi atau kata kerja dapat dijadikan sebagai kunci atau penutup rangkaian pesan verbal yang disampaikan dalam iklan. Bila dihubungkan dengan struktur naskah iklan, kata aksi menempati elemen tindakan (action). Pesan verbal yang berupa kata aksi menjadi bagian penting karena merupakan suatu bentuk perintah bertindak yang ditujukan kepada konsumen. Setelah disajikan informasi tentang produk kemudian konsumen diajak atau disuruh melakukan suatu tindakan, dan tindakan itulah yang sangat diharapkan oleh produsen.

Contohiklan:

"Banyakhal pertamayang dialamisi kecil.Karenamya beri diaSustagen HP dengan Mind Pro."

"Masukangin, perut kembung, kok, repot-repot, oleskan aja minyaktalon Nyonya Meneer."

"Pakai dong Ovale, dengan ovale, yangmengandung ekstrakalamilidah buaya, kulitkujadilembut berseri..."

Di samping kata-kata aksi seperti minumlah, oleskan aja, pakai, dan beri seperti contoh iklan di atas, masih banyak kata aksi yang sering digunakan dalam pesan verbal iklan. Kata-kata tersebut antara lain: belilah, rasakanlah, cobalah, saksikanlah, dapatkan, mulailah, nikmatilah, temukan, ingatlah, lindungi, tentukan, dan sebagainya.

\section{Klimaks}

Klimaks dalam pengertian umum adalah mencapai puncak. Untuk sampai pada posisi puncak tentu melalui tahapantahapan. Dalam hubungannya dengan penyajian pesan verbal, klimaks diartikan sebagai upaya penataan dan pengurutan gagasan atau pikiran mulai dari yang terkecil menuju ke yang lebih besar. Urutan gagasan-gagasan sebelumnya. Dengan menata urutan pikiran demikian itulah diharapkan iklan menjadi lebih mengena pada diri konsumen. Pada umumnya dalam iklan pemanfaatan bentuk klimaks dilakukan dengan menunjukan intensitas bahan baku, fungsi, dan kegunaan produk yang ditawarkan.

Contohiklan:

"Jerawat, kulit kasar, berminyak, noda-noda hingga yang datang terlah dini, merupakan topeng tropis yang mengganggu kecantikan alami. Kikislah dengan Masker Sari Ayu."

"Pelembabyang selalu memyejukkam, namum tampa berminyak, kesegaran, kelembaban mumialami bagikulit, sangat segar dan sangat mudah meresap. LindungikulitAnda dengan kelembaban segartahan lama."

"Rambut kuat, panjang, imdah, dam lembut alami, dengan Sunsilkyangmemberikan nutrition pada rambutAnda."

\section{Repitisi}

Repitisi (repetition) atau pengulangan, yaitu pengulangan bunyi, suku kata, kata atau bagian kalimat yang dianggap penting untuk memberikan tekanan dalam sebuah konteks yang sesuai. Dalam kaitannya dengan pesan verbal dalam iklan, 


\section{JURNAL DAKWAH DAN KOMUNIKASI}

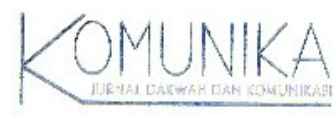

pengulangan dapat dilakukan dengan; (a) penggunaan kata yang sama untuk memulai setiap paragraf dalam iklan, (b) pencantuman dan penyebutan nama perusahaan atau merk secara berulang-ulang.

Salah satu wujud pengulangan yang sering dimanfaatkan dalam iklan adalah aliterasi. Aliterasi adalah pengulangan dengan menekankan pada aspek kemiripan suara atau pengulangan bunyi vokal. Pengulangan bunyi vokal tersebut pada akhirnya akan membentuk suatu irama sehingga pernyataan iklan mengandung nilai estetis dan enak didengar. Sebagaimana yang dikatakan oleh Well, dkk." bahwa bahasa iklan lebih mirip dengan bahasa puisi. Aliterasi dalam iklan merupakan salah satu penegas bahasa iklan seperti bahasa puisi, bahasa yang penuh keindahan.

\section{Contoh iklan:}

"Minum Andecsetiap hari, tulangkutumbuh, tumbuh, dantumbuh..."

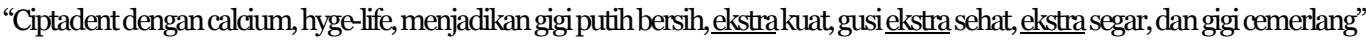

"Kejutan besar, Sugus jumbo, yogurt kunyah nikmatnya, jumbo ... yogurt... kunyah .... kunyah... nikmatnya. Paling besar kunyahnya. Kaya rasabuahnya...gedenikmatnya..."

\section{Pertanyaan Retoris}

Pertanyaan retoris secara sederhana diartikan pertanyaan yang tidak memerlukan jawaban secara pasti karena jawaban yang dibutuhkan biasanya sudah diketahui. Pertanyaan retoris sebagai salah satu bentuk gaya bahasa, merupakan suatu bentuk penegasan dengan menggunakan kalimat Tanya. Bentuk kalimat tanya tersebut cenderung ke arah menyatakan kesangsian atau bersifat mengejek. Sifat pertanyaan retoris adalah kesangsian, pertanyaan yang tidak perlu dijawab, dan bernada ejekan.

Pertanyaan retoris dalam iklan digunakan untuk memberikan kesan umum bahwa produk yang ditawarkan menjadi satu-satunya alternatif yang dibutuhkan. Dengan bentuk pertanyaan retoris tersebut dapat memberi kesempatan kepada konsumen untuk membuat kesimpulan secara mandiri berkaitan dengan segala hal menyangkut produk yang diiklankan. Melalui pertanyaan retoris konsumen menjadi sangsi, penasaran, dan akhirnya tertarik untuk membuat jawaban atas pertanyaan tersebut.

Contoh iklan:

"Manalagiselain di McD. Lebih ringan, lebih lezat, kini dengan harga lebih hemat...mana lagi, selain di Mc.D.

"Pakai Clear, ketombesiapatakut?” berseri."

"Kecantikan tata rias wajah bermula dari kecantikan kulit wajah. Tetapi berapa baryak di antara kita yang bangun dengan wajah halus dan

"Anda mengira sudah saatnya anakAnda minum susu sapi atau fullcream, bukan? Apa saja yang ada dalam Promitetapitidakada dalam sususapi..."

"Semuaibu ingin melindungianaknya, tetapiapakah begitucaramya. Beri dia Gain Advance."

\section{Metafora}

Metafora adalah suatu bentuk analogi yang membandingkan dua hal secara langsung tanpa kata pembanding eksplisit. Metafora pada prinsipnya merupakan suatu cara penyampaian gagasan dengan teknik tidak langsung. Gagasan atau pikiran tersebut "dibungkus" dengan ungkapan atau kalimat metaforis yang di dalamnya terkandung kemungkinan-kemungkinan penafsiran. 
Dalam komunikasi sehari-hari metafora sering diidentikan dengan aspek kesantunan dalam berinteraksi. Selain metofora, juga dikenal bentuk kesantunan bahasa, yakni eufimisme. Baik metafora maupun eufimisme adalah pengungkapan gagasan dengan pemanfaatan kekayaan bahasa dengan memanipulasi tujuan komunikasi. Penggunaan metafora dalam pesan verbal iklan dilakukan dengan cara; (a) penggantian ciri relasi, (b) penataan kembali hubungan yang diawali dengan asosiasi, (c) konseptualisasi, dan (d) analogi berdasarkan acuan setiap kata. ${ }^{12}$

Contohiklan:

"NiveaSun BlockLotion. Perisaikeindahan kulitdarisinarmatahari."

“Taranasiku, bikin kamu sehebat keinginanmu...”

"Hemaviton. Hidup sehat, nikmat bahagia. Hemaviton sisicerah kehidupan.”

\section{MOTIF-MOTIF PESAN DALAM IKLAN}

Iklan pada dasarnya merupakan suatu hasil kerja kreatif yang kompleks. Di belakang sebuah iklan yang baik adalah konsep yang kreatif. Konsep kreatif merupakan bagian dari suatu ide besar yang dapat membuat pesan iklan sebagai pesan yang khas (dinstinctive message), mudah mendapat perhatian (attention getting), dan mudah diingat (memorable).

Di samping pihak produsen, pada umumnya yang terlibat dalam proses kreatif pembuatan iklan adalah biro iklan (advertising agency), dan rumah produksi (production house). Biro iklan terlibat dalam penciptaan ide kreatif, sedangkan rumah produksi berkaitan dengan implementasi ide menjadi suatu visualisasi nyata. Dalam praktiknya, biro periklanan memerlukan seorang ahli seni (art director) untuk menciptakan key-visual, seorang penulis naskah (copy writter) untuk menciptakan key-words, dan seorang pengatur produksi (production director) untuk menciptakan key-sound melalui j̈nggle atau hook.

Proses kreatif dalam penyusunan iklan pada prinsipnya berkenaan dengan salah satu elemen dasar komunikasi, yaitu pesan. Dengan demikian, tahapan-tahapan kreatif dalam proses penciptaan iklan pada dasarnya diarahkan agar dapat membuat pesan iklan berhasil dan efektif. Keberhasilan dan efektivitas tersebut ditinjau dari dua aspek, yakni efektif dari aspek komunikasi dan efektif dari aspek pemasaran. Sebagai bentuk komunikasi pesan iklan dapat diterima dan dipahami oleh khalayak. Selanjutnya, sebagai bagian dari strategi pemasaran, iklan menentukan peningkatan penjualan produk barang dan jasayang ditawarkan.

Dalam perspektif analisis wacana, seorang penulis naskah (copy writter) pada biro iklan merupakan pihak yang menghasilkan teks/wacana. Seorang penulis naskah menduduki posisi sebagai penutur atau orang yang mengkonstruksi wacana iklan. Oleh karena itu, untuk mengetahui makna teks iklan, diperlukan analisis kognisi menyangkut keberadaan diri seorang penulis naskah iklan.

Kognisi mengandung pengertian kesadaran mental yang dimiliki seseorang dalam menanggapi suatu peristiwa. Ditinjau dari perspektif psikologi, kognisi berkaitan dengan respon aktif terhadap suatu peristiwa. Kognisi berhubungan dengan perhatian (attention), pengetahuan (knowledge), pemahaman (understanding), daya ingat (memory), dan kesadaran (awareness)..13

Untuk menciptakan daya tarik pesan, para penulis iklan membuat teks/wacana yang mengacu pada motif psikologis dalam diri manusia. Berdasarkan motif-motif psikologis itulah pesan iklan diolah agar dapat mempengaruhi dan menggerakkan seseorang untuk berperilaku sesuai dengan isi pesan iklan.

Motif-motif psikologis yang dimanfaatkan oleh penulis iklan antara lain berupa; (a) imbauan informasional (rasional), (b) imbauan emosional, (c) imbauan takut, dan (d) imbauan ganjaran. Imbauan rasional didasarkan pada anggapan bahwa manusia pada dasarnya makhluk rasional sehingga untuk meyakinkan seseorang harus disajikan bukti-bukti dan pendekatan logis. Imbauan emosional dilakukan dengan menggunakan kata-kata atau pernyataan yang menyentuh emosi khlayak. 


\section{JURNAL DAKWAH DAN KOMUNIKASI}

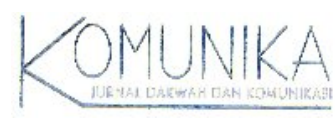

Imbauan takut, disajikan dengan menggunakan kata-kata atau pernyataan yang menampilkan pesan kecemasan, ketakutan, ancaman, dan keresahan pada diri khalayak. Selanjutnya, imbauan ganjaran, disajikan dengan menggunakan rujukan yang menjanjikan sesuatu jika seseorang menggunakan atau membeli produk tertentu. Berikut ini diuraikan wujud motif-motif psikologis yang terdapat dalam teks iklan.

\section{Imbauan Pesan Informasional (Rasional)}

Informasi (informational), yakni pesan yang menekankan pada penyajian fakta, pengetahuan, dan persuasi yang bersifat logis. Pesan informasional dapat disamakan dengan imbauan rasional dalam konsep imbauan pesan (message appeals). Imbauan rasional didasarkan pada anggapan bahwa manusia pada dasarnya adalah makhluk rasional. Sebagai makhluk rasional manusia akan melakukan reaksi pada imbauan emosional bila imbauan rasional tidak ada. Menggunakan imbauan rasional berarti meyakinkan orang lain dengan pendekatan logis atau penyajian bukti-bukti. ${ }^{4}$

Pesan informasional atau imbauan rasional dalam iklan mengindikasikan bahwa aspek utama iklan adalah sebagai pemberi informasi. Iklan merupakan media untuk menyajikan informasi yang sebenarnya kepada masyarakat tentang produk yang akan atau sedang ditawarkan kepada konsumen. Dengan kata lain, sifat dan kandungan kebenaran menjadi bagian penting dalam iklan.

Berkaitan dengan penggunaan aspek verbal dalam iklan, isi pesan yang menekankan formula informasional (rasional) dilakukan dengan berbagai cara. Cara penyajian isi pesan informasional, yaitu (1) penjelasan bahan baku, (2) sifat dan kegunaan produk, dan (3) hubungan sebab-akibat.

\section{a. Penjelasan Bahan Baku}

Penjelasan tentang bahan baku produk digunakan oleh pembuat iklan sebagai salah satu cara mempersuasi khalayak sasaran. Melalui penjelasan bahan baku produk yang ditawarkan, pihak produsen berusaha meyakinkan konsumen dengan menampilkan kandungan produk. Seringkali bahan baku produk dijelaskan dengan menggunakan istilah-istilah teknis dan ilmiah.

Pemanfaatan istilah-istilah tersebut diharapkan mampu menarik khalayak untuk memilih produk yang ditawarkan. Dalam hal ini, kadar rasionalitas dan kelogisan isi pesan yang disampaikan didasarkan pada data ilmiah yang menyertai produk yang ditawarkan. Semakin lengkap dan berkualitas dari segi bahan baku produk dari pandangan ilmiah, semakin rasional pesan yang disampaikan.

Sebagai upaya untuk meyakinkan khalayak, penjelasan tentang bahan baku produk disertai dengan komentar ahli atau juga penjelasan tentang hasil uji klinis. Pernyataan (claim) bahwa produk tertentu sudah memenuhi standar uji klinis diyakini dapat membawa aspek rasionalitas pada diri konsumen untuk sampai pada keputusan membeli dan menggunakan produk tersebut. Di bawah ini kutipan iklan yang menegaskan hal di atas.

"Pakai Ciptadent, phus calcium dengan nutris lengkap, hasil teknologilion Jepang, dengan vitamen E, hygi-lifedan fluoride."

"Formula action WAP, memutihkan plus memperkuat gigi, pasta gigi dengan fturoride, pastagigi Formula ...."

\section{b. Kegunaan Produk}

Dalam membangun dan menata isi pesan informasional, pembuat iklan juga menggunakan sifat dan kegunaan produk. Iklan jenis ini berusaha menilai barang dari segi keandalan sifat dan fungsi barang. Hal itu dilakukan dengan menggunakan pernyataan atau klaim verbal sepert; sempurna, kukuh, awet, dan sebagainya.

Penyajian aspek rasional melalui pernyataan (bahasa verbal) yang mengandung penilaian pada kegunaan barang dapat dikelompokkan ke dalam empat tingkatan (Arifin, 1992). Pertama tingkaf positif, yakni penilaian dari segi sifat dan guna barang dengan menerangkan keadaan normal atau biasa. Kedua tingkat komparatif, penilaian barang dari segi sifat dan guna barang dengan menampilkan barang melebihi barang tertentu lainnya sebagai pembanding. Ketiga, tingkat superlatf, yakni 


\section{JURNAL DAKWAH DAN KOMUNIKASI}

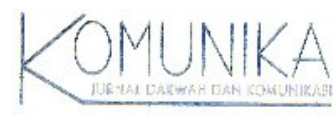

penilaian sifat dan guna barang dengan pernyataan atau klaim bahwa keadaan barang yang ditawarkan mengungguli keadaan beberapa atau semua nomina lain yang dbandingkan. Keempat, tingkat eksesif, pernyataan penilaian yang berusaha menegaskan bahwa barang yang ditawarkan tidak bisa dibandingkan dengan produk lain.

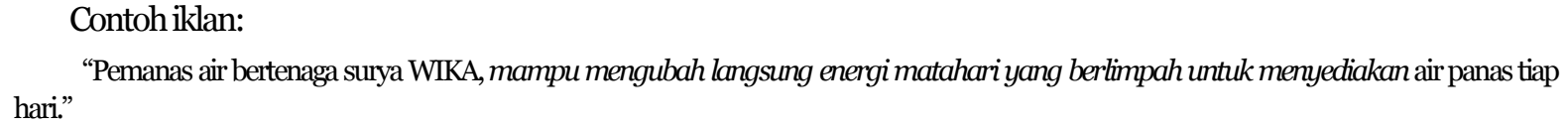

“Ampuh membersihkan toiletAnda. Rangkaian clean Bowl memberikandanmerawatklosetAnda dengan sempurna...”

"Finesse shampoo, memiliki "time control formula". Formula khusus yang membersihkan rambut secara sempurna tampa menghilangkanzatalamiah pelindung rambut."

\section{c. Hubungan Sebab-akibat}

Sebagaimana dalam tradisi berpikir ilmiah, dalam iklan hubungan kasualitas juga dimanfaatkan dalam rangka mempersuasi konsumen sasaran. Dalam hal ini, pembuat iklan menampilkan suatu fakta, peristiwa, atau kasus sebagai pijakan untuk menawarkan produk yang diiklankan. Fakta, peristiwa, maupun kasus tersebut sedapat mungkin sesuatu yang dekat dengan khalayak sasaran dan mudah diterima oleh logika awam. Berangkat dari hal itulah pembuat iklan baru memasuki alam pikiran konsumen dengan menawarkan solusi yang diharapkan menjadi solusi yang logis dan diterima. Ukuran atau kriteria kelogisan bergantung pada fakta, peristiwa maupun kasus yang ditampilkan. Beberapa iklan berikut ini menjelaskan fenomena di atas.

"Karena anakAnda menjadiprioritaspertama.Anchor Milkpantas menjadipilihan utamaAnda."

"Enfaprojugabebasgulapasir sehinggamenghindarikebiasaananakmemyukairasa manisyang berlebihan."

"Senangnya jalan-jalan, tapi lihatlah! Apa saja dipegang, padahal lingkungan semakin tak ramah. Ancaman kuman bertambah, khawatir?Tentutidak! Keluargakuterlindung sepanjang hari. Lifeboy..."

\section{Imbauan Pesan Emosional}

Pesan emosional (emotional message), yakni isi pesan yang menggunakan imbauan psikologis (psychological appeal) seperti rasa takut dan cinta untuk menyentuh rasa. Isi pesan emosional merupakan pemanfaatan bentuk-bentuk kebahasaan atau bentuk-bentuk verbal yang merujuk pada pemaknaan secara emosional. Di samping karena pengaruh rasionalitas, diduga kebanyakan tindakan manusia lebih didasarkan pada emosi. Untuk menegaskan hal itu, Doviat ${ }^{15}$ menyebutkan bahasa manusia (massa) mempunyai otak kecil, tetapi hatiyang besar.

Emosional sebagai suatu istilah terkait dengan konsep emosi dalam perspektif psikologi. Emosi (emotion) diartikan hasutan perasaan atau kesanggupan merasakan dengan kelembutan hati dan sedikit emosi (Webster, 1961:839). Menurut J.B. Watson ada tiga emosi dasar yang dimiliki oleh manusia, yaitu (1) ketakutan (fear), (2) marah (rage), dan (3) cinta (love). Tiga emosi dasar tersebut nantinya bisa berkembang masing-masing menjadi kegelisahan (anxiety), kemarahan (anger), dan rasa simpati (symphaty).

Imbauan motivasional, yaitu pernyataan-pertanyaan verbal yang menyentuh kondisi internal manusia. Kondisi intern dalam diri manusia pada umumnya dikalisifikasikan dalam dua bagian; motif biologis dan motif psikologis. Yang termasuk motif biologis antara lain kenikmatan, kesenangan, kemewahan, dan sebagainya, sedangkan motif psikologi antara lain pengalaman, petualangan, ambisi, kesetiaan, kekeluargaan, simpati, kebanggaan, kemuliaan, perhatian, dan sebagainya ${ }^{16}$ 


\section{JURNAL DAKWAH DAN KOMUNIKASI}

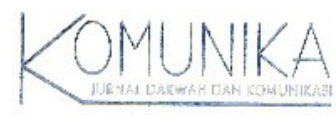

Pembuatan iklan berusaha menggali motif-motif tersebut di atas dengan kata dan ungkapan yang mengandung makna motivasional di atas. Kata-kata yang digunakan adalah kata-kata yang mempunyai konotasi yang merujuk pada beberapa bentuk motifmanusia.

\section{Contoh iklan:}

"Nachitulah bedanya, hemaviton energy drink, pelepas dahaga, penambahtenaga, hemoviton sisicerah kehidupan."

"Penampilan rambut bisa menipu, saat menyentuh baru percaya. Shampo Pantene, kuyakin saat kusentuh, begitu sempurna, terasa sehatrya, itulah pantene."

"Makin besar saldonya, doubleuntung."

"Keceriaan bayiadalah kebahagiaamibu.Zwitsal dengan avobiotonic, begitu lembut dan aman merawat kulit."

\section{Imbauan Pesan Rasa Takut}

Dalam imbauan takut, isi pesan verbal berupa pernyataan-pernyataan yang menampilkan sisi kecemasan, bentuk ancaman atau meresahkan. Pada prinsipnya manusia secara alamiah mempunyai berbagai keterbatasan. Keterbatasanketerbatasan yang menyangkut diri pribadi tersebut menjadi fokus dalam pesan yang menekankan aspek emosional, seperti perasaan takut cepat tua, takut tidak percaya diri, takut dianggap ketinggalan zaman, kecemasan akan hari depan, kecemasan dalam pergaulan, dan sebagainya.

Contohiklan:

"Balita selalu meletakkan apapun di mulutnya sehingga bakteri dapat mengganggu pencernaan. Untung ada BalitaI."

"Sesak nafas karena asma, datang tiba-tiba dan sangat mengganggu serta memyiksa. Asmasolon tindakan awal untuk sesak nafas. Asmasolonmenolong disaattakterduga."

"Berbagai upaya telah dilakukan untukmengatasi kanker. Lindumgimilik Anda yang paling berharga ini, kanker hindarisedini mungkin. Femafit secarateratur. Singkirkan kekhawatiran Anda. Biasakan hidup sehat."

"Rambut rontok, bikin aku khawatir. Maka aku hanya pakai yang pasti, Neril mengatasi kerontokan rambut, karena setiap helai rambut begituberharga."

\section{KONTEKS SOSIAL DAN PENCITRAAN DALAM IKLAN}

Citraan (image), yakni isi pesan yang mencoba menampilkan asosiasi antara produk dan gaya hidup, masyarakat kelas atas (glamorous people) dan simbol-simbol modernisasi. Citra itu sendiri sebagai suatu konsep mengandung pengertian keseluruhan informasi tentang dunia ini yang telah diolah, diorganisasikan, disimpan individu ${ }^{17}$ Citra juga diartikan sebagai suatu dunia menurut persepsi kita karena ia adalah gambaran tentang realitas dan tidak harus sesuai dengan realitas.

Dalam kaitannya dengan dunia periklanan, pembuat iklan (produser) berusaha melakukan pembentukan dan pengubahan citra tertentu sesuai dengan produk yang ditawarkan. Seperti yang dikatakan Robert ${ }^{18}$ bahwa komunikasi, termasuk komunikasi periklanan, tidak secara langsung menimbulkan perilaku tertentu, tetapi cenderung mempengaruhi cara kita mengorganisasikan citra kita tentang lingkungan. Pada akhirnya citra itulah yang mempengaruhi cara kita berperilaku.

Pembentukan citra dalam iklan melalui penyajian isi pesan verbal dilakukan dengan beberapa cara, yaitu (1) perintisan, (2) aspek kewaktuan, (3) aspek lokatif, dan (4) pembatasan.

\section{Perintisan}

Pembuat iklan melakukan pembentukan dan pengubahan citra atau image melalui pernyataan-pernyataan verbal yang mengandung makna perintisan. Perintisan berarti produsen menyampaikan pesan kepada khalayak dengan keyakinan bahwa yang diproduksinya merupakan perintis, pembuka jalan atau yang pertama. Perintisan dapat dilakukan dari segi waktu keluarnya maupun segi mutu dan keunggulannya.

Contohiklan:

"Baru dari susu bendera. BenaMilk. Susu khusus bayiusia 6-12 bulan.Pertama diIndonesia." 


\section{JURNAL DAKWAH DAN KOMUNIKASI}

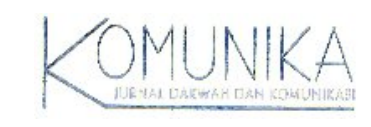

"Persembahan terbaru dariSharp, lemari es extrabig freezer."

"Kini,Anda dapat menikmati kemudahan dari Acuvue, lensa kontak sekali pakai yang pertama di dumia dariJohnson \&Johnson."

“Generasibaru Esteem MitSporty, partnerideal Anda waktuberolahraga.”

"Kuku Bima TL, formula baru, teruji secara klinis dapat meningkatkan hormone dan sel sperma pria.”

\section{Aspek Kewaktuan}

Kehidupan modern salah satunya ditandai oleh adanya efisiensi dalam segala hal. Salah satu ukuran efisiensi dapat dilihat dari dimensi kewaktuan. Dalam hal ini efisiensi tidak selalu identik dengan waktu yang singkat. Sebaliknya, pada bagian lain efisiensi justru menerangkan cakupan waktu yang lama. Hal-hal yang terkait dengan dimensi kewaktuan itulah yang dimanfaatkan dalam penataan pesan verbal iklan.

Contohiklan:

"Bila setiap detik begitu berharga. SLIOO, Onemoretime."

“Daridulu saya pilih Bimoli, karena sudahterkenal mutunya. Bimolikesempurnaan minyakgoreng."

"Pelembut raga Tanjung. Lapisan tiraimentarisejuksepanjang hari."

“Pepsodent kesehatan gusi dengan zinc citrat dan triclosan untukperlindungan total gigi dan gusi dariwaktu kewaktu.”

\section{Aspek Lokatif}

Yang dimaksud aspek lokatif, yaitu pernyataan verbal yang menyangkut penyebutan suatu tempat atau wilayah tertentu. Penyebutan tempat atau wilayah tersebut dihubungkan dengan penciptaan citra pada produk yang ditawarkan. Penyebutan tempat atau wilayah tersebut biasanya dihubungkan dengan sumber utama bahan yang ditawarkan, citra tempat atau wilayah sehubungan dengan produk yang ditawarkan dan sebagainya. Sekadar contoh dapat dikemukakan, Roma (Italia) untuk rujukan mode, Paris untuk rujukan kosmetik, pegunungan atau daerah pedesaan untuk rujukan keaslian dan aspek natural produk.

Contohiklan:

"Hugie-dry comfort. Dengan sistem anti bocor dan berdaya serap tinggi, plus lapisan udara, nyaman bebas iritasi. Huggies-dry comfort, nomor1diAmerika."

"Pemirsa, Bodrex telah menjadiobat sakit kepala Nusantara, pereda sakit kepala, selalu okesetiap saat."

"Bronchicum, obat batuk alamiah yang diformulasikan dari ekstrak berbagai tumbuhan berkhasiat dari bemua Amerika dan daratan Cina, diperkuat dengan ekstrak tumbuhan primulae, thymi dan pipmpniae..”

"Kami datang dari Bandung dan Paris, Jakarta dan Washington DC, Hongkong dan Tokyo. Tujuan kami satu: melayani Anda. Hanya di DaiChi Hold,Jakarta."

\section{Pembatasan}




\section{JURNAL DAKWAH DAN KOMUNIKASI}

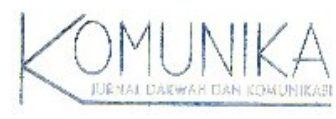

Iklan jenis ini memberi makna pembatasan sehingga menyiratkan hal khusus yang hanya diperoleh bila menggunakan produk tertentu yang ditawarkan iklan tersebut. Strategi pembatasan dapat disejajarkan dengan konsep positioning dalam strategi periklanan pada umumnya. Melalui strategi tersebut produsen berusaha menempatkan produknya di tengah persaingan produk lain yang ada di pasaran.

Contohiklan:

"Anda semuatentu sudahmengenal karpet. Tetapi karpet Nobel hamyaada satu."

"Pemulas mata Refill Sari Ayu memungkinkan Anda memilih warna-warna pemulas mata yang Anda suka. Benar-benar hamya warna yang Andasuka."

\section{PENUTUP}

Berdasarkan uraian di atas dapat dikatakan bahwa pembuat iklan, khususnya copy writer, mempunyai kebebasan yang luas dalam merekayasa bahasa untuk kepentingan penyampaian pesan. Mereka dapat memanfaatkan kekayaan bahasa seluas-luasnya untuk pencapaian efektvitas pesan. Akan tetapi, ada satu hal yang perlu dipertimbangkan, yaitu menyangkut keberadaan konsumen. Bagaimanapun bentuk dan cara rekayasa bahasa tersebut ada batasnya. Salah satu pembatasnya adalah kepentingan konsumen.

Berkaitan dengan konsumen, khususnya menyangkut pesan verbal, sudah upaya yang dilakukan untuk melindungi kepentingan konsumen. Perlindungan tersebut sebagaimana tertuang dalam kode etik periklanan. Dalam kode etik dinyatakan bahwa iklan tidak boleh menggunakan kata-kata yang berlebihan sepert, "ter-", "paling”, "nomor satu”, dan katakata sejenis tanpa menjelaskan dalam bidang dan hal apa keunggulan itu.

Bagaimanapun canggihnya rekayasa bahasa dalam iklan, keputusan tetap berada pada diri konsumen. Oleh karena itu, penyajian suatu fakta yang mengandung kebenaran merupakan tuntutan tersendiri dalam iklan. Hal itu akan menjadi bagian penting bila dihubungkan dengan perkembangan kondisi saat ini. Seperti dikemukakan Keraf (1998) bahwa masyarakat semakin kritis dan tidak mudah dibohongi atau bahkan ditipu oleh pernyataan-pernyataan dalam iklan.

\section{ENDNOTE}

${ }^{1}$ Frank Jefkins, Periklanan (Jakarta: Penerbit Erlangga, 1996).

${ }^{2}$ Umberto Eco, Theory of Semiotics (Bloomongton. Indiana Univ. Press, 1979).

${ }^{3}$ Burhan Bungin, Imaji Media Massa: Konstruksi dan Makna Realitas Iklan Televisi dalam Masyarakat Kapitalistik (Yogyakarta: Penerbit Jendela, 2001).

${ }^{4}$ Jalaludin Rakhmat, Psikologi Komunikasi (Bandung: Penerbit: Rosda Karya, 1998), hal. 223.

${ }^{5}$ Ibid.

${ }^{6}$ Burhan Bungin, Imaji Media Massa.

${ }^{7}$ Tamrin Amal Tamagola. "Citra Wanita dalam Iklan" dalam Ibrahim (Ed.) Wanita dan Media, Konstruksi Idielogi Gender dalam Ruang Publik Orde Baru (Bandung: Rosda Karya, 1998), hal. 333.

${ }^{8}$ Burhan Bungin, Imaji Media Massa.

${ }^{9}$ Stewart L. Tubs and Sylvia Moss, Human Comunication, Prinsip-prinsip Dasar, Terj. Dedy Mulyana dan Gembirasari (Bandung: Rosda Karya, 1996).

${ }^{10}$ Frank Jefkins, Periklanan, hal. 229.

${ }^{11}$ William, J. BumettWells dan Sandra M., Advertising Principles and Practice (London: Prince Hall, 1989), hal. 340.

${ }_{12}^{2}$ Aminuddin, Stilistika: PengantarMemahami Bahasa dalam Karya Sastra(Semarang. Penerbit IKIP Semarang, 1988), hal. 113.

${ }_{13}$ William J. BumetWells dan Sandra M., Advertising, hal. 193.

${ }^{14}$ Jalaludin Rahmat, Psikologi Komunikasi, hal. 299.

${ }^{15}$ lbid.

${ }^{16}$ Jalaludin Rahmat, Psikologi Komunikasi, hal. 302. 


\section{JURNAL DAKWAH DAN KOMUNIKASI}

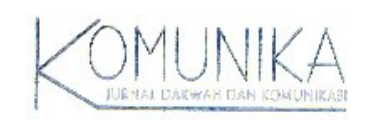

${ }^{17}$ Ibid.,hal. 223.

${ }^{18}$ Ibid., hal. 224.

\section{DAFTAR PUSTAKA}

Aminuddin. 1995. Stilistika: PengantarMemahami Bahasa dalam Karya Sastra. Semarang. Penerbit IKIP Semarang.

Bungin, Burhan. 2001. Imaji Media Massa: Konstruksi dan Makna Realitas Iklan Televisi dalam Masyarakat Kapitalistik. Yogyakarta: Penerbit Jendela.

Dyer, Gillian. 1996. Advertising as Communication. England: Clay Ltd. St Ives Plc.

Eco, Umberco. 1979. Theory of Semiotic. Bloomington: Indiana Univ. Press.

Eriyanto. 2006. Analisis Wacana, Pengantar Analisis Teks Media. Yogyakarta: Penerbit LKiS.

Jefkins, Frank. 1996. Peniklanan. Jakarta: Penerbit Erlangga.

Rahkmat, Jalaludin. 1998. Psikologi Komunikasi. Bandung. Penerbit: Rosda Karya.

Tamagola, Tamrin Amal. 1998. "Citra Wanita dalam Iklan" dalam Ibrahim (Ed.) Wanita dan Media, Konstruksi Idielogi Gender dalam Ruang Publik Orde Baru. Bandung: Rosda Karya.

Tubbs, Stewart L. and Sylvia Moss. 1996. Human Comunication, Prinsip-prinsip Dasar. Terj. Dedy Mulyana dan Gembirasari. Bandung: Rosda Karya

van Dijk, Teun A. 1998. New Discourse. Hillsdale. New Jersey: Lawrence Enbaum Associates.

van Dijk, Teun A. 2007. "Critical Discourse Analysis", dalam http://www.hum.uva.n//teun

Wells, William, J. Bumett, and Sandra M. 1989. Advertising Principles and Practice. London. Prince Hall. 